\title{
Why patients consult and what happens when they do
}

\author{
Edwin Martin, Daphne Russell, Sandra Goodwin, Roger Chapman, Michael North, Peter Sheridan
}

Bedford MK40 3NG Edwin Martin, FRCGP, general practitioner Sandra Goodwin, NDN, research nurse

Department of Public Health, University of Aberdeen, Aberdeen Daphne Russell, FSs, statistician

\section{Leighton Buzzard LU7 7AR \\ Roger Chapman, FRCGP, general practitioner}

Maryland Sea, Essex Michael North, MRCGP, general practitioner

\section{Bedford MK42 0NT}

Peter Sheridan, MRCGP, general practitioner

Correspondence to: $\mathrm{Dr}$ Edwin Martin, 2 Goldington Road, Bedford MK40 3NG.

BMF 1991;303:289-92

\section{Abstract}

Objective-To study patients' perceptions of why they consulted the doctor, how ill they thought they were, and what happened in the consultation. To compare patients' perceptions before and after the consultation and to compare these perceptions with those of the doctor.

Design-Patients filled in a questionnaire before and after the consultation. The doctor filled a questionnaire in after the consultation.

Setting - Three general practices in Bedfordshire and one in Hertfordshire.

Patients -500 consecutive patients consulting in each practice.

Main outcome measures-Changes in patients' perceptions and differences between the perceptions of patients and doctors.

Results-Doctors perceived patients to be less ill than the patients themselves did. Patients from social classes IV and $V$ and children perceived themselves to be more ill than the average. Patients perceived themselves to be less ill after the consultation. A third of patients attended because doctors had told them to, and a quarter of patients had already tried to treat their problem themselves when they attended the consultation. Doctors' perceptions of the consultation emphasised listening, supporting, and giving advice. Patients' perceptions emphasised prescribing, reassuring, and referring to a consultant. Doctors perceived that they listened, examined, and gave advice less to social classes IV and $V$ than to social classes I, II, and III and gave explanations more often to men than to women. Patients perceived external factors rather than lifestyle factors as being more important in causing their problems.

Conclusion-Doctors' perceptions of patients' problems differed from those of patients expressed both before and after their consultation. Doctors' and patients' perceptions also differed about the consultation itself. The consultation reassured some patients.

\section{Introduction}

Traditionally, medicine has dealt with patients and diseases. A patient is a person who has a disease, which has a cause. If the cause is dealt with then the disease will disappear and the patient will become a person again. This paradigm has, however, been increasingly challenged.' 'Zola has shown that the basic reason for many consultations is not that the person has a disease. ${ }^{2}$ Stewart et al have shown that the severity of the symptom is not the only cause of its presentation to the doctor $^{3}$-anxiety about a symptom or pressure by friends and family to present a symptom to the doctor may be just as important.

This process may be complicated by the fact that patients are often either ignorant or misinformed about basic psychological facts ${ }^{4}$ and the seriousness of their symptoms. ${ }^{5}$ Patients may also misunderstand the role of treatments - for example, wanting prescriptions for penicillin for viral sore throats. ${ }^{6}$ Effective communication and investigations of patients' beliefs and anxieties have been found to improve the management of problems such as hypertension.

We examined patients' reasons for contacting their doctors and their perceptions of their problems before and after consultation. We also sought their perceptions of what happened in the consultation and compared these with the doctors' perceptions.

\section{Method}

The project was carried out in three general practices in Bedfordshire and one in Hertfordshire, with one male partner in each practice taking part. The study was piloted in each practice. Each partner attempted to assess 500 consecutive consultations.

Before patients saw the doctor the aim of the survey was explained to them and they were asked to complete a form and post it in a box in the waiting room. The form asked what they had come to see the doctor about, the cause of their problems, and how ill they thought they were (not at all ill, slightly ill, ill, very ill) and gave a list from which to choose one or more reasons why they had come to the doctor on that particular day (see table V). Each form was numbered consecutively and the number put on the patients notes. After the consultation the doctor asked the patient to complete another form and post it in the box in the waiting room before leaving. This form, which was numbered by the doctor from the number on the notes, asked what the patients had come to see the doctor about, the cause of their problem, and how ill they thought they were. This form gave a list from which to choose what the doctor had done for them during the consultation (see table VI). Patients could choose one or more options and volunteer others. When the patient was aged less than 13 the parent or escort was asked to fill in the forms.

After the consultation the doctor filled in a form that listed the same options of what the doctor had done for the patient and asked for the patient's sex, race, age, and occupation, whether the patient had been seen about this problem in the past six months, and the nature of the contact (appointment, non-appointment, clinic). This form was also numbered, all three forms could be matched by the numbers.

Results were analysed with the $\chi^{2}$ test and McNemar test.

\section{Results}

Altogether 1972 completed sets of forms were obtained from the 2184 issued, with doctors obtaining similar numbers of completed sets (range 483-498). More women were seen than men, and men were less likely to complete the forms. Doctors saw 146 patients 
(7\%) aged $0-5$ years, $163(8 \%)$ aged 6-15, $410(21 \%)$ aged 16-25, 651 (33\%) aged 26-45, $436(22 \%)$ aged $46-$ 65 , and $166(8 \%)$ older than 65 years. The lower the social class the higher the proportion of patients not completing the forms (table I). Age was not associated with completion of the forms.

\section{NATURE AND CAUSE OF PROBLEM PRESENTED AT CONSULTATION}

According to the patients' assessment the commonest problems were related to ear, nose, and throat (203); vague symptoms (202); chest problems (122); skin problems (120); locomotive problems (118); and pregnancy (120). Concerning the cause of their problem, 275 patients did not know the cause before consultation compared with 219 afterwards $(\mathrm{p}<0.001, \mathrm{McNemar}$ test). Doctors believed that they could positively identify the cause of the problem in 1557 cases (79\%). The commonest causes of problems were perceived by patients to be infection, trauma, stress and social problems, physical and environmental factors, and pregnancy. Doctors perceived obesity, alcohol, and

TABLE I-Completed forms by social class of patients

\begin{tabular}{lcc}
\hline Social class & No of patients & $\begin{array}{c}\text { No }(\%) \text { of } \\
\text { completed forms }\end{array}$ \\
\hline I & 89 & $86(97)$ \\
II & 468 & $431(92)$ \\
III & 793 & $729(92)$ \\
IV & 404 & $359(89)$ \\
V & 289 & $239(83)$ \\
Tot recorded & 141 & $128(91)$ \\
\hline
\end{tabular}

$\chi^{2}$ for trend $=23 \cdot 4, \mathrm{p}<0 \cdot 001$.

TABLE II -Causes of illness leading to consultation. Values are numbers of patients who mentioned the cause (percentage of total patients)

\begin{tabular}{lccc}
\hline & \multicolumn{2}{c}{ Patient's perception } & \\
\cline { 2 - 3 } & Before consultation & After consultation & Doctor's perception \\
\hline Infection & $211(11)$ & $261(13)$ & $613(31)$ \\
Trauma & $94(5)$ & $89(5)$ & $190(10)$ \\
Stress; social problems & $65(3)$ & $69(3)$ & $203(10)$ \\
Physical and environmental factors & $51(3)$ & $51(3)$ & $10(<1)$ \\
Pregnancy & $47(2)$ & $41(2)$ & $198(10)$ \\
Obesity & $3(<1)$ & $3(<1)$ & $21(1)$ \\
Alcohol & 0 & $1(<1)$ & $14(1)$ \\
Smoking & $3(<1)$ & $15(1)$ & $33(2)$ \\
Don't know & $275(14)$ & $219(11)$ & $408(21)$ \\
\hline
\end{tabular}

TABLE III-Perception of how ill patients were. Values are numbers (percentages)

\begin{tabular}{|c|c|c|c|}
\hline & \multicolumn{2}{|c|}{ By patient } & \multirow[b]{2}{*}{ By doctor } \\
\hline & Before consultation & After consultation & \\
\hline Not at all ill & $799(41)$ & $848(43)$ & $851(43)$ \\
\hline Men & 258 & $271(36)$ & 288 \\
\hline Women & $541(44)$ & $577(47)$ & $563(46)$ \\
\hline Slightly ill & $710(36)$ & 696 & $924(47)$ \\
\hline Men & $296(39)$ & $309(41)$ & $392(52)$ \\
\hline Women & $414(34)$ & $387(32)$ & $532(44)$ \\
\hline Ill & $308(16)$ & $261(13)$ & $188(10)$ \\
\hline Men & $132(17)$ & $106(14)$ & $70(9)$ \\
\hline Women & $176(14)$ & $155(13)$ & $118(10)$ \\
\hline Very ill & $31(2)$ & $23(1)$ & $9(<1)$ \\
\hline Men & $15(2)$ & $12(2)$ & $2(<1)$ \\
\hline Women & $16(1)$ & $11(1)$ & $7(<1)$ \\
\hline No response & $124(6)$ & $144(7)$ & \\
\hline Men & $55(7)$ & $58(8)$ & \\
\hline Women & $69(6)$ & $86(7)$ & \\
\hline
\end{tabular}

$\mathrm{p}<0.001$ ( $\chi^{i}$ tests), men $v$ women.

TABLE IV -Number (\%) of patients perceived to be ill or very ill

\begin{tabular}{lccc}
\hline & \multicolumn{2}{c}{ By patients } & \\
\cline { 2 - 3 } & Before consultation & After consultation & By doctor \\
\hline Practice A $(n=483)$ & $58(12)$ & $40(8)$ & $37(7)$ \\
Practice $B(n=494)$ & $84(17)$ & $69(14)$ & $39(8)$ \\
Practice C $(n=498)$ & $99(20)$ & $80(16)$ & $50(10)$ \\
Practice $D(n=497)$ & $95(19)$ & $95(19)$ & $73(15)$ \\
\hline
\end{tabular}

smoking as causing problems, but patients rarely nominated these before their consultation (table II), and only for smoking was this perception adopted by patients after the consultation.

\section{HOW ILL PATIENTS PERCEIVED THEMSELVES TO BE}

On consulting the doctor three quarters of the patients perceived themselves as either not ill at all or slightly ill (table III). This proportion increased after the consultation -144 patients felt better and 55 felt worse, but $89 \%$ of patients' perceptions remained unchanged. The improvement in perception of health was significant $(p<0.05$ or better, McNemar tests forpaired comparisons) for both sexes, all social classes, three of the four doctors, and all age groups apart from the 45-65 group. Doctors perceived patients to be less ill than patients did themselves, with the greatest discrepancy among the youngest patients. Compared with women, men were significantly less likely to perceive themselves as not ill at all $(\mathrm{p}<0.001)$, and doctors concurred with this assessment (table III).

Before the consultation patients in social classes IV and $\mathrm{V}$ perceived themselves as more ill than did patients in other classes $(187(16 \%)$ patients in classes I-III said they were ill or very ill compared with 141 $(25 \%)$ in classes IV and V); $\left(\chi^{2}=22 \cdot 9, \mathrm{df}=1, \mathrm{p}<0.001\right)$. Doctors also perceived these patients to be more ill, but this difference was not significant.

The four doctors' perceptions of how ill their patients were varied, as did their patients' perceptions (table IV). The age, sex, and social class mix of the four doctors' patients may have contributed to these differences: practices $\mathrm{C}$ and $\mathrm{D}$ had a significantly higher proportion of women, practice $\mathrm{B}$ more patients in social class $\mathrm{V}$, and practice $\mathrm{D}$ older patients.

\section{REASONS FOR ATTENDANCE AT CONSULTATION}

The commonest reasons why patients attended were that their symptoms had become worse, the doctor had asked them to come, or their symptoms were interfering with their life. One quarter of patients had first tried to treat themselves and attended only after this had failed (table V). Men were more likely to attend because they were worried that their condition might be serious or because they needed a certificate. Patients in social classes IV and V were more likely than those in classes I-III to attend because they needed a certificate $(88$ $(15 \%) v 50(4 \%), \mathrm{p}<0.001)$, were worried that their condition might be serious (131 (22\%) v $160(13 \%)$, $\mathrm{p}<0.001)$, or had been told by somebody else to come $(88(15 \%)$ v $113(9 \%), \mathrm{p}<0.001)\left(\chi^{2}\right.$ tests, $\left.\mathrm{df}=1\right)$.

\section{WHAT THE DOCTOR DID IN CONSULTATION}

The doctor perceived more activities occurring in the consultation than did the patient (a mean of 3.5 and $2 \cdot 5$, respectively). The activities "examine you," "listen to your worries," "give you advice," "explain your illness," "arrange tests or $x$ rays," "give other help," and "refer you to somebody else" were each mentioned significantly more commonly (all $\mathrm{p}<0.001$ ) by doctors than patients and "explain that you will get better" was mentioned significantly more commonly by patients.

The five most important activities were determined from the proportions of answers mentioning a particular activity. Patients and doctors placed different emphasis on these. Patients gave more emphasis to prescribing, reassuring, and referring to a consultant than did doctors, whereas doctors gave more emphasis to listening, supporting, giving advice, and examining. Doctors and patients agreed that there were fewer interventions among the $16-25$ year olds. According to the doctors almost all the under $5 \mathrm{~s}$ were examined $(121 / 125,97 \%)$ but only $652 / 881(74 \%)$ patients over 25 were examined. Overall, only about half the patients thought that an examination had taken place. Patients and doctors 
TABLE v-Reasons why patient came to doctor. Patients could give more than one reason. Values are numbers (percentages)

\begin{tabular}{lccl}
\hline Reason & Men $(\mathrm{n}=756)$ & Women $(\mathrm{n}=1216)$ & Total $(\mathrm{n}=1972)$ \\
\hline $\begin{array}{l}\text { My symptoms became worse } \\
\text { The doctor told me to come back } \\
\text { to see him }\end{array}$ & $245(32)$ & $415(34)$ & $660(33)$ \\
$\begin{array}{l}\text { My symptoms were interfering } \\
\text { with my life }\end{array}$ & $217(29)$ & $370(30)$ & $587(30)$ \\
$\begin{array}{l}\text { My own treatment did not work } \\
\begin{array}{l}\text { was worried in case I had } \\
\text { something serious }\end{array}\end{array}$ & $227(30)$ & $310(25)$ & $537(27)^{\star}$ \\
$\begin{array}{l}\text { Somebody told me to come to } \\
\text { the doctor }\end{array}$ & $138(18)$ & $292(24)$ & $509(26)^{\star}$ \\
$\begin{array}{l}\text { I wanted something explained } \\
\text { to me }\end{array}$ & $94(12)$ & $142(12)$ & $280(14)^{\star \star \star}$ \\
$\begin{array}{l}\text { I needed a certificate } \\
\text { Another reasont }\end{array}$ & $78(10)$ & $128(11)$ & $222(11)$ \\
\hline
\end{tabular}

* Men $v$ women, $\mathrm{p}<0.05\left(\chi^{2}\right.$ test, $\left.\mathrm{df}=1\right)$.

列

tIncludes 214 patients consulting for antenatal care or contraception.

agreed that the over $65 \mathrm{~s}$ were more likely than other age groups to receive a prescription. Men perceived more activities per consultation than did women (mean $2 \cdot 8$ and $2 \cdot 6$, respectively), although the average number of activities perceived by the doctor did not vary by the patient's sex. Men and women differed significantly in their perceptions: women were more likely to say that the doctor had examined them and had given advice, and men to say that the doctor had explained their illness and said that they would get better; the doctors were significantly more likely to say they gave advice to, examined, arranged tests and $x$ rays for, and listened to women than men; and more likely to explain the illness to men (table VI).

As social class moved from I and II to IV and V doctors considered that they explained and listened to a decreasing proportion but gave "other help" to an increasing proportion of patients. Doctors also perceived that they examined patients from social classes IV and V more and gave them advice less often (table VII). However, perceptions of what happened during the consultation did not differ as greatly among patients of differing social classes as it did among different doctors, so these results should be interpreted with caution

\section{Discussion}

Al Jumail and Martin carried out a study similar to ours on a small number of patients in a Saudi Arabian primary care department; it showed widely varying views between doctors and patients. ${ }^{8}$ The design of their questionnaire may have affected the validity of the information. The questionnaire defined options followed in some questions by an open option. The order of the questions may have affected the way in which they were answered and the nature of the response to the open option.

In our study, defining the severity of the illness and what comprised an examination varied according to the doctors and the patients, making it impossible to standardise these terms. For example, many patients did not perceive measuring blood pressure to be an examination. As we compared the perception of patients and doctors by using terms in common use this lack of standardisation probably does not seriously affect the findings.

The fact that the four reasons most commonly chosen by patients for consulting appeared in the first five given in the list raises the possibility of this response having been governed by the order of the questions.

All four doctors perceived patients to be less ill than patients considered themselves to be, and after consultation patients felt significantly better than before, although most felt unchanged. Patients from social classes IV and V perceived themselves, and parents of children under 5 perceived them, to be significantly more ill than did other patients, and these patients were more reassured by the consultation.

Only one third of patients stated that they consulted the doctor specifically because of the severity of their symptoms. When asked why they consulted the doctor, male patients and patients from social classes IV and V more commonly recorded that they were worried that they might have something seriously wrong. Patients from social classes IV and V were more likely to have been sent to the doctor by somebody else, and this may reflect a habit of discussing their illness within their social groups. Conclusions about patients from social classes IV and V should, however, be guarded: about one in six patients from these social groups failed to complete the survey forms.

There was an interesting difference in the emphasis given to various activities in the consultation. Whereas doctors emphasised listening, supporting, giving advice, and examining, the patients emphasised prescribing, reassuring, and referral to a consultant. Three out of four of the activities emphasised by the doctors involved helping patients to help themselves, whereas patients emphasised activities that entailed either having things done to them or being told that they would get better. This may reflect patients' perceptions of their role in the consultation as a passive

TABLE VI-Emphasis on what the doctor did for the patient in the consultation. Values are numbers (percentages)

\begin{tabular}{|c|c|c|}
\hline & By patient & By doctor \\
\hline Examine you & $893(45)$ & $1374(70)^{\star \star \star}$ \\
\hline Men & $289(38)$ & $443(59)$ \\
\hline Women & $604(50) \ddagger$ & $931(77) \ddagger$ \\
\hline $\begin{array}{l}\text { Listen to your worries and } \\
\text { give you support }\end{array}$ & $594(30)$ & $1138(58)^{\star \star \star}$ \\
\hline Men & $216(29)$ & $408(54)$ \\
\hline Women & $378(31)$ & $73060) \dagger$ \\
\hline $\begin{array}{l}\text { Give you tablets, medicine, } \\
\text { or other prescription }\end{array}$ & $1022(52)$ & $1084(55)$ \\
\hline Men & $387(51)$ & $411(54)$ \\
\hline Women & $635(52)$ & $673(55)$ \\
\hline Explain what your illness is & $771(39)$ & $1059(54)^{\star \star \star}$ \\
\hline $\begin{array}{l}\text { Men } \\
\text { Women }\end{array}$ & $\begin{array}{l}350(46) \ddagger \\
421(35)\end{array}$ & $\begin{array}{l}432(57)+ \\
627(52)\end{array}$ \\
\hline Give you advice & $629(32)$ & $1037(53)^{\star \star \star}$ \\
\hline $\begin{array}{l}\text { Men } \\
\text { Women }\end{array}$ & $\begin{array}{l}199(26) \\
430(35) \ddagger\end{array}$ & $\begin{array}{l}269(36) \\
768(63) \ddagger\end{array}$ \\
\hline Explain that you would get & & \\
\hline better & $213(28) t^{485(25)}$ & $150(20)^{395(20)^{\star \star}}$ \\
\hline Women & $272(22)$ & $245(20)$ \\
\hline Arrange for tests or $x$ ray film & is $\quad 210(11)$ & $303(15)^{\star \star \star}$ \\
\hline Men & $80(11)$ & $74(10)$ \\
\hline Women & $130(11)$ & $229(19) \ddagger$ \\
\hline $\begin{array}{l}\text { Refer you to a hospital } \\
\text { consultant }\end{array}$ & $141(7)$ & $125(6)$ \\
\hline Men & $64(8)$ & $54(7)$ \\
\hline Women & $77(6)$ & $71(6)$ \\
\hline Refer you to somebody else & $73(4)$ & $119(6)^{\star \star \star}$ \\
\hline $\begin{array}{l}\text { Men } \\
\text { Women }\end{array}$ & $\begin{array}{l}27(4) \\
46(4)\end{array}$ & $\begin{array}{l}48(6) \\
71(6)\end{array}$ \\
\hline $\begin{array}{l}\text { Arrange for you to have } \\
\text { an injection }\end{array}$ & $27(1)$ & $18(1)$ \\
\hline $\begin{array}{l}\text { Men } \\
\text { Women }\end{array}$ & $6(<1)$ & $4(<1)$ \\
\hline $\begin{array}{l}\text { Women } \\
\text { Give you any other help }\end{array}$ & $21(2)$ & $253(13)^{\star \star \star}$ \\
\hline Men & $58(8)$ & $100(13)$ \\
\hline Women & $101(8)$ & $153(13)$ \\
\hline
\end{tabular}

$\star \star \mathrm{p}<0.01 ; \star \star \star \mathrm{p}<0.001$ (McNemar test) patients $v$ doctors $\mathrm{tp}<0.01$. $\neq \mathrm{p}<0.001\left(\chi^{2}\right.$ test, $\left.\mathrm{df}=1\right)$ men $v$ women.

TABLE VII - Social class differences in perceptions of what happened in the consultation. Values are numbers (percentages) of consultations

\begin{tabular}{lclc}
\hline & $\begin{array}{c}\text { Classes I and II } \\
(\mathrm{n}=517)\end{array}$ & $\begin{array}{c}\text { Class III } \\
(\mathrm{n}=729)\end{array}$ & $\begin{array}{c}\text { Classes IV and } \\
\mathrm{V}(\mathrm{n}=598)\end{array}$ \\
\hline Doctor's perceptions: & & & \\
$\quad$ Explaining and listening & $310(60)$ & $384(53)$ & $279(47)^{\star}$ \\
Examination & $328(63)$ & $472(65)$ & $478(81) \dagger$ \\
Giving advice & $338(65)$ & $490(67)$ & $339(57) \dagger$ \\
Tests performed & $79(15)$ & $153(21) \dagger$ & $88(15)$ \\
Other help & $57(11)$ & $134(18)$ & $157(27)^{\star}$ \\
Patient's perceptions: & & & \\
$\quad$ Explaining and listening & $158(31) \dagger$ & $165(23)$ & $139(23)$ \\
Tests performed & $41(8)$ & $50(7)$ & $80(13) \dagger$ \\
\end{tabular}

${ }^{\star} \mathrm{p}<0.001 ; \chi^{2}$ test for trend. $\quad \mathrm{tp}<0.001, \chi_{0}^{2}$ test, $\mathrm{df}=1$. 
one. The fact that doctors perceived that they listened, explained things and gave advice less, and gave other help and examined patients more when the patients were from social classes IV and V may reflect the doctors' tendency with patients from these social classes to undertake physical activity more and educate patients less. This trend, and the fact that the doctors gave explanations more to men than to women, may reflect difficulties for the four male doctors from social class $I$ in relating to patients of a different sex and different social classes.

The fact that the proportion of patients who were aware of the nature of their problem rose from $28 \%$ before the consultation to only $32 \%$ after the consultation suggests that the consultation had little educative value. When we look at the causes patients perceived for their problems, however, the most frequently mentioned causes were infection, trauma, stress and social problems, physical and environmental factors, and pregnancy. These relate to a belief that health is governed largely by external factors not under the control of the individual. ${ }^{10}$ With regard to lifestyle factors that affect health, such as obesity, alcohol, and smoking, these were perceived by doctors - but not by patients - to cause problems. Only in the case of smoking was this view adopted by patients after the consultation.

The wide divergence between doctors and patients about how ill the patient is, the cause and nature of the problem, and the content of the consultation emphasises the gap between doctors' and patients' perceptions. The doctors participating in this project clearly need to study and adjust their consultation styles to communicate better with their patients.

\footnotetext{
1 McWhinney IR. Changing models: The impact of Kuhn's theory on medicine. Fam Pract 1983;1:3-8.

Zola IK. Pathways to the doctor--from person to patient Soc Sci Med 1973:7:677-89.

Stewart MA, McWhinney IR. Buck CW. How illness presents: a study of patient behaviour. F Fam Pract 1975;2:411-4

4 Johnson SM. Snow LF, Mayhew HE. Limited patient knowledge as reproduction risk factor. F Fam Pract 1978;6:855-62.

5 Walker RD. Knowledge of symptoms suggesting malignant disease amongs general practitioner patients. I R Coll Gen Pract 1982;32:163-6. general practitioner patients. F $R$ Coll Gen Pract 1982,32:163-6. Brett AS, Mattieu AE. Perceptions and behaviour of patients with upper respiratory tract infections. f Fam Pract 1982;15:277-9.

7 Johnson SS. Health beliefs of hypertensive patients in a family medicin residency programme. F Fam Pract 1979;9:877-83.

8 Al Jumail S, Martin E. Primary care in a military community in Saudi Arabia. Update 1983;27:959-64

9 Belson W, Duncan JA. A comparison of the check list and open response questioning systems. Applied Statistics 1962;11:120-32.

10 Coulter A. Lifestyles and social class: implications for primary care. $\mathcal{F} R \mathrm{Col}$ Gen Pract 1987;37:533-6.

(Accepted 23 April 1991)
}

Needs Assessment Unit in the Departments of Public Health, City and Hackney

Health Authority, and General Practice and Primary Care, The Medical Colleges of St Bartholomew's and The London Hospitals, London Ann Bowling, PHD, senior lecturer

Bobbie Jacobson, FFPH, director of public health Lesley Southgate, PHD, senior lecturer

Juliet Formby, DCR, research assistant

\section{Correspondence to:} Dr A Bowling, Department of General Practice and Primary Care, St Bartholomew's Hospital Medical College, London EC1A 7BE.

\title{
General practitioners' views on quality specifications for "outpatient referrals and care contracts"
}

\author{
Ann Bowling, Bobbie Jacobson, Lesley Southgate, Juliet Formby
}

Abstract

Objective-To ascertain general practitioners' views about which quality specifications should be included in contracts for hospital care.

Design-In depth interview study and postal survey.

Setting-General practitioners in City and Hackney Health District.

Subjects-Fourteen doctors were interviewed in depth; 77 of 131 doctors (59\%) returned postal questionnaires.

Main outcome measure-Rating of listed quality specifications.

Results-The most popular items which doctors thought should be included in contracts by April 1991 related to the availability of patients' notes in outpatient clinics, respect shown to general practitioners in telephone communications with hospital doctors, supply of medicines after discharge, patient management plans for general practitioners, the earlier arrival of discharge slips, the type of hospital doctor to see new outpatients, and the unnecessary duplication of investigations.

Conclusions-A high premium was attached by general practitioners to effective organisation, effective communication between primary and secondary sources of care, and effective communication with patients.

\section{Introduction}

The white paper Working for Patients states that in future each district health authority will be responsible for buying "the best service it can from its own hospitals, from other authorities' hospitals, from self governing hospitals, or from the private sector." Hospitals and community health services will have to satisfy districts that they are delivering a high quality and cost effective service, and their performance will be monitored by district health authorities. ${ }^{12}$ Hopkins and Maxwell have given examples of measures that patients might like to see specified in a contract for service (for example, length of waiting lists, quality of explanations given, standards of care). ${ }^{3}$ They suggested that the main considerations of quality in drawing up contracts for services should include access to services, communication, technical safety and effectiveness, hotel services, discharge procedures, aftercare, patien outcome, equity, relevance to need, and value for money.

General practitioners are the gatekeepers of the National Health Service. Most patients who attend hospital outpatient departments and many emergency and most non-emergency inpatient hospital admissions of patients are referred by general practitioners. This, along with the proposal for general practitioners to hold their own budgets, has major implications for use of resources. The National Health Service and Community Care Act 1990 acknowledges the importan part played by the general practitioner in acting as proxy for the health service user, and health authorities are expected to consult local general practitioners over the development and content of contracts for health care. $^{4}$

\section{Present study}

Members of the general practitioners' forum and the purchasing group in the City and Hackney Health District commissioned the survey of general practitioners presented here. The aim was to ascertain general practitioners' views about which quality specifications should be included in contracts for hospital care. An underlying aim was to assess how much information, and of what quality, could be obtained in the time scale imposed by the need to set contracts for April 1991. This led to a combined approach of in depth interviews and a postal survey. 